\title{
Willingness to Pay (WTP) for an Improved Environmental Quality in Ebonyi State, Nigeria
}

\author{
Christian Nwofoke, Sylvia Chinasa Onyenekwe, Festus Ugwuoke Agbo \\ Department of Agricultural Economics, University of Nigeria, Nsukka, Nigeria \\ Email: chinasa.onyenekwe@unn.edu.ng, Christian.nwofoke.pg.65909@unn.edu.ng, fuagbo4real@yahoo.com
}

How to cite this paper: Nwofoke, C., Onyenekwe, S.C. and Agbo, F.U. (2017) Willingness to Pay (WTP) for an Improved Environmental Quality in Ebonyi State, Nigeria. Journal of Environmental Protection, 8, 131-140.

https://doi.org/10.4236/jep.2017.82011

Received: September 23, 2016

Accepted: February 13, 2017

Published: February 16, 2017

Copyright $\odot 2017$ by authors and Scientific Research Publishing Inc. This work is licensed under the Creative Commons Attribution International License (CC BY 4.0).

http://creativecommons.org/licenses/by/4.0/

\begin{abstract}
Increasing generation of rice husk requires better quality disposal options in Ebonyi State, Nigeria. The common practice has been incineration or dumping into dumpsite. The enormous heaps of these rice husks which have piled up since the 1960s now constitute nuisance. Removal of this rice husk from the environment is urgently needed because of the environmental pollution and health hazards it poses to the people and the environs. This study estimates the willingness to pay (WTP) for improved waste disposal services. Findings indicated that about 95\% (152) of the households were willing to pay for removal of rice husk waste with an average amount of N957. Factors that positively affected WTP for the removal of rice husk from the environment include annual income (0.001), years of education (0.013), farm size (0.051), age (0.025) and farming experience (0.008), while household size (0.003) and distances of homes/farms from rice mill centers (RMCs) (0.001) were inversely related to WTP with the $\mathrm{R}^{2}$ value of $77 \%$. About $90 \%$ (144) of the respondents generated rice husk with an average of 23 bags $(\mathrm{kg})$. The study therefore recommends among others that through the help of extension agents, the general public should be informed on the need for waste recycling and the need for attitudinal change towards recycled product.
\end{abstract}

\section{Keywords}

Rice Husk, Willingness to Pay, Environmental Quality

\section{Introduction}

Nigeria is West Africa's largest producer of rice, producing currently an average of 3.1 million tonnes of paddy rice annually [1]. Rice cultivation is widespread within Nigeria extending from the northern to the southern zones with most rice grown in the eastern and middle belt of the country [2]. The demand for rice has increased at a much faster rate in Nigeria. Also, rice production rose gradually 
over the years with area expansion driven by population growth and urbanization [3]. To produce rice, by-products such as rice husk are generated in the rice milling process. This husk accounts for approximately $20 \%-23 \%$ of total paddy rice weight (rice crop weight) [4]. The quantity of rice milling by-products generated in Nigeria annually was estimated at about 1,032,993.6 metric tonnes [5].

Recently, the Federal Government of Nigeria began to focus on agriculture as a means of diversifying the current crude oil dependent economy in the face of the dwindling oil price and rice is one of the agricultural products that have been earmarked for scaling up. This means that the quantity of rice husk produced will increase. Ebonyi State is a major rice producing state located in the eastern part of Nigeria. Rice husk dumps are increasing in alarming proportions in the state especially in Abakaliki where Abakaliki rice mill industry which is the first and major rice mill company in Ebonyi state is located. Husk from rice produced since the early 1960s, has been preserved in dump sites, towering above the rusty iron sheets of the Abakaliki Rice Mill market and other rice milling centers in the state. Currently, there are over 5000 workers, 2500 rice milling machines and a production capacity of more than 11,000 metric tonnes per month, which in turn leads to generation of husks that are commensurate to the quantity of paddy [6]. For every $1000 \mathrm{kgs}$ of paddy milled, about $220 \mathrm{kgs}(23 \%)$ of husk is produced, and when this husk is burnt in the boilers, about $55 \mathrm{kgs}$ (25\%) of Rice Husk Ash (RHA) is generated [7]. Rice husk is abundant in Ebonyi State. This has been reported severally in the literature [6] [8] [9].

Disposing these rice husk dumps is important to avert the environmental pollution and health hazards it poses to the people and the environs [7]. In attempt to dispose rice husk, most communities set the rice husk dumps on fire. Unfortunately, a small heap of rice husk takes months to get burnt to ashes. Even when burnt to ashes, it is still an eyesore in the communities especially during the rainy season. Rice husk dump on fire also constitutes serious health hazards especially during the harmattan season when the dust devil and other manner of winds blow. It can set nearby buildings on fire. Some people are known to have died by unknowingly running into or stepping into rice husk dumps on fire beneath the surface. In some cases, the husks are dumped indiscriminately around the rice mills where it undergoes uncontrolled fermentation and purification. Evacuation of such heaps of rice husk from the environment has become a big problem due to lack of commercial interest. Private sector involvement in the waste disposal business is a probable alternative solution to the disposal problem, thereby, turning an environmental liability into a socioeconomic and poverty alleviation asset.

Previous studies such as [10] focused on determination of efficiency of resource use in swamp and upland rice production system in Ebonyi state; [11] on the effects of crop residue such as rice husk on soil properties; [12] on use of rice husk as low cost building materials; [13] on the effect of delignification on the saccharification of Abakaliki rice; and [14] on comparative analysis of resource use efficiency in rice production among Fadama III and non-Fadama III benefi- 
ciary rice farmers in Niger State, did not address the issue of rice husk disposal in Ebonyi State. There seem to be uncertainties in public awareness and attitudes toward rice husk disposal. Hence, the present study seeks to investigate the willingness to pay for the removal of rice husk from the environment to improve the environmental quality and public health. And furthermore, determine the socio-economic factors influencing the respondents' willingness to pay for the removal of rice husk from the environment. Therefore, the null hypothesis socio-economic characteristics of households do not significantly determine their willingness to pay for the removal of rice husk from the environment was tested.

\section{Theoretical Framework}

\subsection{Contingent Valuation Method}

Contingent-valuation method (CVM) will be used in this study to determine the willingness per household head to pay for an improved environmental quality in the study area. The (CVM) measures both use and non-use values [15]. This method uses a survey to determine the willingness to pay (WTP) for a particular environmental good or willingness to accept compensation (WTA) for a loss of a particular environmental or public good. It provides a direct method of measuring the value of natural resources without resorting to the market-valuation method. The range of environmental issues it addresses is wide such as air quality, water quality, waste management, sanitation improvements, biodiversity, health impacts, natural resource damage and environmental risk reductions.

The CVM application can be split into six stages, namely, setting up the hypothetical market, obtaining bids, estimating the mean WTP and/or WTA, estimating bid curves, aggregating the data and the evaluation of CVM [16]. According to [17], by means of an appropriately designed questionnaire, a hypothetical market is described as where the good in question can be traded. The contingent market defines the good itself, the institutional context in which it would be provided, and the way it would be financed. A random sample of people is then directly asked to express or reveal, in some way, their maximum willingness to pay or willingness to accept for a hypothetical change in the level of provision of the good. Respondents are assumed to behave as though they were in a real market.

This method was used by [18], whose study was on WTP for environmental services from trees on communal land in Zimbabwe; In forestry issues as by [19], in the valuation of community forests in Ethiopia; [20], to estimate WTP for community conservation of non-wood forest products in Enugu and cross river states; And [21], to estimate the mean WTP for irrigation water in lower Anambra and lower Benue States. There are three common methods for this, which are: the open ended questioning, interactive bidding, and the dichotomous choice or referendum, which is the most accepted method.

The theoretical framework on which the CVM hinges is the Random Utility Model (RUM) [22] [23]. In this framework the indirect utility of a respondent $(U)$ consist of the deterministic $(D)$ and the stochastic $(\varepsilon)$ component. Also, this 
utility can be influenced by a set of environmental $(E)$ and socio-economic characteristics $(S)$. This is expressed in the equation below:

$$
U_{i j}=D_{i j}\left(E_{i j}, S_{i j}\right)+\varepsilon_{i j}\left(E_{i j}, S_{i j}\right)
$$

In the dichotomous choice form the respondent are asked to choice between two options, the statusquo $(f)$ and the improved quality $(g)$. The probability of the person choosing option $f$ or $g$ is given as:

$$
\begin{aligned}
& P_{i f}=P\left(\varepsilon_{i f}-\varepsilon_{i g}<D_{i g}-D_{i f}\right) \\
& P_{i g}=P\left(\varepsilon_{i g}-\varepsilon_{i f}<D_{i f}-D_{i g}\right)
\end{aligned}
$$

The error terms of the utility is assumed to obey the property of independency from irrelevant alternatives (IIA) [22]. And this states that the relative probability of selecting any two options is independent of other alternatives. The probability that an individual chooses option $\mathrm{g}$ is given by

$$
P_{i g}=\frac{\mathrm{e}^{\left(D_{i g}-D_{i f}\right)}}{1+\mathrm{e}^{\left(D_{i g}-D_{i f}\right)}}
$$

This can be estimated using multinomial log it regression [24].

\subsection{Determinants of Willingness to Pay (WTP) for Environmental Resources}

Empirical studies have shown some socio-economic determinants of WTP. [24] in valuing river quality in china found out that income and never visit to river had significant influence on WTP. While income had a positive influence, never visit to river had a negative influence thus likely those who had higher income were more likely to pay while those who never visited the river were less likely to pay. Also, [25] found out that household income, education of respondents, age and gender had significant effect on respondent's WTP for air pollution clean-up plan with expected positive signs. Older respondents and women had low WTP. Furthermore, [26] found out that income from major occupation, location of respondent (located in the northern as against southern Nigeria), and household size had positive and significant influence on WTP while number of years of farming experience had negative and significant influence on WTP. [27], also found out that occupation (farming), occupation (business), number of years in school, existence of forest management whether organized or not, income and proportion of household food from non-timber forest product (NTFP) plant had positive and significantly influenced amount WTP. WTP was negatively and significantly influenced by location, gender and involvement in NTFP production. [21] noted that occupation (farming), total income, starting price, location by farmer had positive and significant influence on willingness to pay. Willingness to pay was negatively and significantly influenced by location.

\section{Methodology}

The study area is Ebonyi State, which lies approximately within longitudes $7^{\circ} 30^{\prime}$ and $8^{\circ} 30^{\prime} \mathrm{E}$ and latitudes $5^{\circ} 40^{\prime}$ and $6^{\circ} 45^{\prime} \mathrm{N}$ and located in the Eastern part of Ni- 
geria [28]. The state is made up of thirteen local government areas, which are divided into three (3) agricultural zones, namely: Ebonyi North, Ebonyi Central and Ebonyi South. A Multi-stage sampling technique was employed in the selection of the respondents for the study. The three agricultural zones in Ebonyi State were purposively selected because they are all involved in rice production and milling. Purposive sampling was also used to select one LGA (Ikwo) from Ebonyi Central, (Afikpo South) from Ebonyi South and two LGAs (Abakaliki and Izzi) from Ebonyi North agricultural zone based on available rice milling centers. A total of four LGAs were used for the study. Furthermore, there was a selection of one autonomous community from each of the selected LGAs giving a total of four autonomous communities. Again, four villages were selected from each community making a total of sixteen villages. This was followed by a random selection of 10 households from each of the villages, giving a total of 160 respondents for the study. Data for this study were collected from primary sources using a well-structured questionnaire, within a fixed distance of four kilometers from rice milling centers in the study area. And the data was analysed using contingent valuation method.

\section{Results and Discussion}

\subsection{Estimation of WTP for the Removal of Rice Husk from the Environment}

The results of the estimation of willingness to pay (WTP) amount for the removal of rice husk from the environment was presented in Table 1.

From the bid function presented to the households, findings showed that $95 \%$ (152) of the households were willing to pay while 5\% (8) of the households were not. Also, the mean amount a household was willing to pay annually for the removal of rice husk from the environment was N957.1875 approximately N957. Out of the 160 questionnaires completed, 91\% (145) were considered to have valid responses and 9\% (15) is considered to have invalid responses. Out of the 15 respondents, 3.7\% (6) protested, $2.5 \%$ (4) were cases where the maximum WTP was lower than the accepted starting price, while $3.1 \%$ (5) were outliers. Protest zeros were those who protested to WTP questions. They were determined based on the statement the respondent made in his/her response to the follow-up questions to the valuation question. Some of the responses of those categorized as protest zeros include: pay what? the husk is free, the money will not be used

Table 1. Analysis of WTP amount for the removal of rice husk from the environment.

\begin{tabular}{cccc}
\hline Variable & Frequency & Percentage & Mean \\
\hline Valid responses & 145 & 90.6 & \\
WTP lower than starting price & 4 & 2.5 \\
Protested & 6 & 3.7 \\
Outliers & 5 & 3.2 & \\
Total & 160 & 100 & 957.1875 \\
\hline
\end{tabular}

Source: Field survey, 2015. 
properly, government should evacuate it since they collect produce and haulage, nobody can handle things belonging to the public well, the government will take advantage of us, and no good accountability, among others. It is important to note that not all those who gave reasons for not willing to pay are protesters. Outliers include those whose WTP were over $5 \%$ of their income and well above the maximum starting price to be used.

The outliers were few. The occurrence of few outliers could be because the survey was conducted face-to-face in addition to the interviewers being well trained to elicit the information.

During the interview process the interviewers made sure that respondents understood the questions that were asked before providing answers. If a respondent answered a question in a way that showed that the question was not understood, he/she was asked the question repeatedly with explanations until the respondent understood and provided an answer that simply matched the question.

\subsection{The Socio-Economic Factors Influencing the Respondents' WTP for Removal of Rice Husk from the Environment}

From the analysis of responses to the valuation question, the result showed that some variables significantly influenced having a valid or invalid response and this is presented in Table 2. Age; distance from rice mill center-RMC; years of farming/working experience; years of education; farm size; household size; annual income of households were found to be significant.

Education has positive relationship to WTP for the removal of rice husk from the environment. This means that the higher the level of one's education the higher the probability of an individual WTP for a better environmental quality.

Table 2. Tobit result for determinants of WTP in the study area.

\begin{tabular}{cccc}
\hline Explanatory variables & Co-efficient & Standard error & $t$-value \\
\hline Age & 0.0026028 & 0.0011516 & $20.26^{* *}$ \\
Distance from RMC's & -0.0200756 & 0.0059456 & $-3.38^{* * *}$ \\
Yrs of farm/wk. Exp. & 0.0038598 & 0.0038598 & $2.68^{*}$ \\
Yrs of education & 0.0082413 & 0.0032737 & $2.52^{\star *}$ \\
Farm size & 0.0045311 & 0.0023058 & $1.97^{*}$ \\
Household size & -0.0167863 & 0.0054879 & $-3.06^{* *}$ \\
Income & $2.92 \mathrm{e}-07$ & $8.52 \mathrm{e}-08$ & $3.43^{* * *}$ \\
Constant & 0.8162893 & 0.0607675 & $13.43^{* *}$ \\
Log likelihood ratio & -53.746943 & & \\
Chi-square & 86.248 & & \\
$\mathrm{R}^{2}$ & 0.7787 & & \\
\hline
\end{tabular}

$* * *=$ significant at $1 \% ;{ }^{* *}=$ significant at $5 \% ;{ }^{*}=$ significant at $10 \%$ levels respectively. Obs. summary: 8 left-cen- sored observations at WPAY $\leq 0 ; 152$ uncensored observations 0 right-censored observations. Source: Field survey data, 2015. 
The households who had higher education indicated greater WTP and this could be because they knew the importance of cleaner environment to health and productivity.

Household income has a positive relationship to WTP for the removal of rice husk from the environment, implying that the higher the income of the household the higher the probability of the individual's WTP for a good environment. This makes sense because with increased income, individual farmers can afford to pay for improved living conditions.

Age has positive relationship to WTP for the removal of rice husk from the environment. This means that the higher ones age the higher the probability of the individual's WTP for a better environmental quality. The households who were older indicated greater WTP and this was because most of them had higher farm size, more annual income and knew the importance of cleaner environment to health and productivity.

Farm size has a positive relationship with WTP for the removal of rice husk from the environment, implying that the higher the farm size of the household the higher the probability of the individual's WTP for a good environment. This is because increase in farm size increases the quantity of rice paddy produced and hence an increase in rice husk generated which will increase the households WTP for the removal of rice husk from the environment for economic purposes and for improved environmental quality.

Farming/working experience has positive relationship to WTP for the removal of rice husk from the environment. A household who had higher farming/ working experience indicated greater WTP and this was because they knew the importance of cleaner environment to health and productivity.

Household size was found to be inversely related to WTP for removal of rice husk from the environment. This means that the probability of WTP decreases as household size increases. As consumption needs increase, household income reduces, thereby leaving little or none for other expenses.

Distance from the RMC was found to be inversely related to WTP for the removal of rice husk from the environment. This means that the probability of WTP decreases as distance from the rice milling center increases. Since the level of pollution from the rice mill decreases with an increase in distance and the impact on the households decreases with distance as well.

The co-efficient of determination $\mathrm{R}^{2}$ was found to be $77 \%$ implying that the variation in WTP is due to the stated socio-economic characteristics. The mean WTP was \#957; this implies that the households attach value to improvement in environmental quality thereby enhancing their good health and productivity.

The result also showed that the overall Tobit model was significant based on the chi square, implying that the socio-economic variables were significant determinants of WTP for the removal of rice husk from the environment.

The F-statistics at 5\% level showed that the socio-economic characteristics of households significantly determined their WTP for the removal of rice husk from the environment with F-cal. value of 85.37 and F-tab. value of 2.09. There- 
fore the null hypothesis which states that the socio-economic characteristics of households do not significantly determine their WTP for the removal of rice husk from the environment was rejected.

\section{Conclusion and Recommendation}

From the study, it is apparent that majority of the households were willing to pay for the removal of rice husk from the environment with varying degrees of amount (\#) while some protested and some were outliers. On estimation of willingness to pay (WTP), 95\% (152) of the households were willing to pay with an average amount of \#957 while 5\% (8) of the households were not. And from the Tobit regression result, factors that positively affected WTP for the removal of rice husk from the environment include: annual income, years of education, farm size, age and farming experience, while household size and distances of homes and farms from RMC's were inversely related to WTP for removal of rice husk from the environment with the $\mathrm{R}^{2}$ value of $77 \%$.

Therefore, the study recommends that environmental protection agency and other related agencies should adequately sensitize the public on the long-term implications of indiscriminate burning of rice husk as a disposal strategy on the environment and socio-economic wellbeing of households in the concerned communities, and also on the need for waste recycling and the need for attitudinal change towards recycled product.

\section{References}

[1] International Rice Research Institute (IRRI) (2015) World Rice Statistics Online Query Facility. http://ricetoday.irri.org/

[2] Fakayode and Bamidele (2009) Technical Efficiency and Factor Productivity in Upland and Lowland Rice. PhD Thesis Submitted to the Department of Agricultural Economics, University of Ilorin, Ilorin.

[3] Daramola, B. (2005) Government Policies and Competitiveness of Nigerian Rice Economy. Paper Presented at the Workshop on Rice Policy \& Food Security in SubSaharan Africa Organized by WARDA, Cotonou, and Republic of Benin.

[4] International Rice Research Institute (IRRI) (2008) Commercial Rice Milling Systems: Byproducts and Their Utilization, Viewed 3 March 2015.

[5] NAERLS \& PCU (2004) Field Situation Assessment of 2004. In: Ubwa, S.T., Abah, J., Oshido, B.A. and Otokpa, E. (2014) Studies on Urea Treated Rice Milling Waste and Its Application as Animal Feed. African Journal of Pure and Applied Chemistry, 8, 23-31.

[6] Nwofe, P.A. (2013) Comparative Analysis of Domestic Energy Use in Nigeria: A Review. Continental Journal of Renewable Energy, 4, 7-17.

[7] Koteswara, R.D., Pranav, P.R.T. and Anusha, M. (2011) Stabilization of Expansive Soil with Rice Husk Ash, Lime and Gypsum-An Experimental Study. International Journal of Engineering Science and Technology (IJEST), 3, 8076-8085.

[8] Nnabude, P.C. and Mbagwu, J.S. (2001) Physico-Chemical Properties and Productivity of a Nigerian Typic-Haplustult Amended with Fresh and Burnt Rice-Mill Wastes. Journal of Bio-Resource Technology, 76, 265-272. https://doi.org/10.1016/S0960-8524(00)00062-6 
[9] Akanmu, I.Y. and Shridha, M.K.C. (2002) Management of Rice Mill Waste in Abakaliki, Ebonyi State, Nigeria. PhD Thesis Submitted to the Department of Agricultural Economics, Ebonyi State University, Abakaliki.

[10] Nwachukwu, E.U. (2008) Determination of Efficiency of Resource Use in Swamp and Upland Rice Production System in Ebonyi State. An Unpublished M.Sc Thesis Submitted to the Department of Agricultural Economics University of Nigeria, Nsukka, Nigeria.

[11] Ogbodo, E.N. (2010) Assessment of Some Soil Fertility Characteristics of Abakaliki Urban Flood Plains of South-East Nigeria, for Sustainable Crop Production. World Journal of Agricultural Sciences, 7, 489-495.

[12] Opara, P.N. (2011) Low Cost Materials for Building and Construction: A Case Study of Rice Husk. Building Materials Research and development Center Ebonyi State University Abakaliki, Journal of Sustainable Development and Environmental Protection, 1, 131-211.

[13] Ekwe, N.B. (2012) Effect of Delignification on the Saccharification of Abakaliki Rice Husk. Advances in Applied Science Research, 3, 3902-3908.

[14] Mallam, M. (2013) Comparative Analysis of Resource Use Efficiency in Rice Production among Fadama III and Non-Fadama III Beneficiary Rice Farmers in Niger State. An Unpublished M.Sc Dissertation, Department of Agricultural Economics, University of Nigeria Nsukka, Nigeria.

[15] Carson, R., Flores, N. and Meade, N. (2003) Contingent Valuation: Controversies and Evidence. Environmental and Resource Economics, 19, 173-210. https://doi.org/10.1023/A:1011128332243

[16] Hanley, N. and Splash, C.L. (1993) Cost of Benefit Analysis and the Environment. Edward Elgar Publishing Ltd., Cheltenham.

[17] Mitchell, R. and Carson, R. (1989) Using Surveys to Value Public Goods: The Contingent Valuation Method. Resources for the Future, Washington DC.

[18] Lynam, T.J., Campbell, B.M. and Vermeulen, S.J. (1991) Contingent Valuation of Multipurpose Tree Resources in the Smallholder Farming Sector, Zimbabwe. Environmental Economic Unit, Department of Economics, Göteborg University, Göteborg.

[19] Mekonnen, A. (2000) Valuation of Community Forestry in Ethiopia: A Contingent Valuation of Rural Households. Journal of Environmental and Development Economics, 5, 289- 308. https://doi.org/10.1017/S1355770X00000188

[20] Chukwuone, N.A. (2007) Socioeconomic Determinant of Cultivation of Non-Wood Forest Produce in Southern Nigeria. Journal of Biodiversity and Conservation, 18, 339-353. https://doi.org/10.1007/s10531-008-9489-y

[21] Amaechina, E.C. (2013) Economics Analysis of Financing and Sustainability of Irrigated Agriculture in the Lower Anambra and Lower Benue Irrigation Projects. PhD Thesis, Department of Agricultural Economics, University of Nigeria Nsukka, Nigeria.

[22] Luce, R.D. (1959) Individual Choice Behaviour: A Theoretical Analysis. John Wiley \& Sons, New York.

[23] McFadden, D. (1973) Conditional Logit Analysis of Quantitative Choice Behaviour. In: Zarembka, P., Ed., Frontiers in Econometrics, Academic Press, New York, $105-$ 142.

[24] Hanemann, W.M. (1984) Welfare Evaluations in Contingent Valuation Experiments with Discrete Responses. American Journal of Agricultural Economics, 66, 332-341. https://doi.org/10.2307/1240800 
[25] Wittington, D. (2000) Administering Contingent Valuation Surveys in Developing Countries. Environment Economics Program for Southern and Eastern Asia, International Development Research Centre, Singapore. http://www.idrc.ca/uploads/user-S/10536144310ACF2D2.pdf

[26] Chukwuone, N.A. and Agwu, A.E. (2005) Financing Agricultural Technology Delivery in Nigeria: Would Farmers Be Willing to Pay? Journal of Extension Systems, 21, 69-85.

[27] Chukwuone, N.A. (2008) Analysis of Conservation and Utilization of Non-Wood Forest Product in Cross River and Enugu State of Nigeria. PhD Thesis, Department of Agricultural Economics, University of Nigeria Nsukka, Nigeria.

[28] Ebonyi State Economic Empowerment \& Development Strategy (EB-SEEDS) (2004) Draft Report of the EB-SEEDS Committee on Poverty Reduction, Growth and Sustainable Development Strategy for Ebonyi State.

Submit or recommend next manuscript to SCIRP and we will provide best service for you:

Accepting pre-submission inquiries through Email, Facebook, LinkedIn, Twitter, etc. A wide selection of journals (inclusive of 9 subjects, more than 200 journals)

Providing 24-hour high-quality service

User-friendly online submission system

Fair and swift peer-review system

Efficient typesetting and proofreading procedure

Display of the result of downloads and visits, as well as the number of cited articles

Maximum dissemination of your research work

Submit your manuscript at: http://papersubmission.scirp.org/

Or contact jep@scirp.org 